\title{
MEMAHAMI MATEMATIKA DENGAN MUDAH DAN MENYENANGKAN DI SMAN 6 TANGERANG SELATAN
}

\author{
Dewi Purnama Sari ${ }^{1)}$, Isnurani ${ }^{2)}$, R. Aditama ${ }^{3)}$, Usep Rahmat ${ }^{4)}$. \\ 1,2,3,4 Program Studi Matematika, Fakultas Matematika dan Ilmu Pengetahuan Alam, Universitas Pamulang
}

\begin{abstract}
Abstrak
Pengabdian pada masyarakat ini bertujuan untuk memberikan wawasan pengetahuan tentang bagaimana mudahnya dan menyenangkan dalam belajar matematika di SMAN 6 Tangerang Selatan, serta memberikan bekal terhadap peserta didik bagaimana cara belajar dan mempelajari matematika supaya lebih mudah untuk di pahami.Sasaran pengabdian adalah peserta didik di SMAN 6 Tangerang Selatan. Permasalahan diselesaikan dalam tiga tahapan kegiatan yaitu persiapan, pelaksanaan dan evaluasi. Persiapan dilakukan dengan melakukan survey pendahuluan untuk melihat kondisi dilapangan mengenai kesulitan yang dialami peserta didik dalam belajar matematika. Pelaksanaan dilakukan dengan proses pengajaran di dalam dan ruang kelas dengan menggunakan metode ceramah yaitu teknik presentase, dilanjutkan dengan permainan dalam menyelesaikan soal-soal, dan diakhiri dengan post test. Evaluasi kegiatan dilakukan untuk masing-masing tahap dengan mengumpulkan dan menyimpulkan data dari masing-masing tahapan kegiatan.Hasil kegiatan pelatihan menunjukan tingkat keberhasilan dengan indikasi adanya kesesuaian materi dengan materi yang sedang dipelajari di sekolah, adanya respon yang positif dari peserta didik, dan sebagian besar $(75 \%)$ peserta didik telah memahami materi barisan dan deret.
\end{abstract}

Kata Kunci: Mudah dan Menyenangkan Belajar Matematika, Karya Ilmiah

\begin{abstract}
This community service aims to provide insight into knowledge about how easy and fun it is to learn mathematics at SMAN 6 Tangerang Selatan, and provide provisions for students how to learn and learn mathematics so that it is easier to understand. The target of dedication is students at SMAN 6 South Tangerang. The problem is resolved in three stages of activities, namely preparation, implementation and evaluation. Preparation is done by conducting a preliminary survey to see the conditions in the field regarding the difficulties experienced by students in learning mathematics. The implementation is carried out by the teaching process in and in the classroom using the lecture method, namely the percentage technique, followed by games in solving the questions, and ends with a post test. Activity evaluation is carried out for each stage by collecting and concluding data from each activity stage. The results of training activities show the level of success with an indication of the suitability of the material with the material being studied in school, a positive response from students, and most (75\%) students have understood the material sequences and rows
\end{abstract}

Keywords: easy and fun learning mathematics, scientific work 


\section{PENDAHULUAN}

\subsection{Analisis Situasi Permasalahan}

Matematika mempunyai peranan penting dalam kehidupan manusia. Diantaranya berperan dalam mengatasi permasalahan manusia dalam kehidupan sehari-hari. Pada saat ini kemampuan matematik dan keterampilan menggunakan matematika merupakan kebutuhan penting bagi manusia. Tanpa bantuan konsep dalam matematika dan proses matematika yang mendasar manusia akan banyak mendapat kesulitan. Sehingga manusia membutuhkan matematika sebagai alat dalam memenuhi kebutuhan hidup sehari-hari. Oleh karena itu matematika penting untuk dipelajari.

Beberapa siswa SMA masih ada yang mengalami kesulitan belajar matematika, sehingga mempengaruhi hasil belajar matematika dan pelajaran lain yang berkaitan dengan kemampuan matematik. Kesulitan siswa tersebut berdampak pada hasil belajar matematika siswa yang rendah.

Pada pelajaran tingkat SMA kesulitan yang sering dihadapi terdapat pada materi terkait aljabar dan penerapanya. Dalam materi ini, masih ada siswa yang belum mencapai hasil belajar matematika dengan optimal. Kenyataan ini dapat dilihat dari hasil belajar pada subpokok ini pada tahun-tahun sebelumnya, di mana masih banyak siswa yang belum mencapai ketuntasan belajar. Kesulitan yang dialami siswa dikarenakan kurangnya pemahaman konsep dalam menyelesaikan soal-soal pada materi tersebut, dalam pemahaman prosedur pengerjaan juga masih banyak melakukan kesalahan, sehingga hasil belajar yang optimal belum tercapai.

Metode pembelajaran merupakan faktor penting dalam meningkatkan hasil belajar matematika siswa. Kurang tepatnya seorang guru dalam memilih suatu metode pembelajaran akan berpengaruh terhadap hasil belajar siswa. Seperti penggunaan metode pembelajaran yang kurang cocok dengan materi pembelajaran, serta pemahaman guru terhadap metode-metode pembelajaran yang masih kurang, juga merupakan faktor rendahnya hasil belajarmatematika siswa. Sehingga guru harus dapat memilih dan menggunakan metode yang tepat untuk menyampaikan materi kepada siswa.

Proses pembelajaran matematika terdapat bermacam-macam metode mengajar. Metode mengajar yang digunakan oleh guru di sekolah adalah metode ekspositori yaitu guru menjelaskan materi pokok bahasan dan siswa menerimanya. Secara umum dalam metode ini guru menjelaskan teori dan definisi pokok bahasan kemudian memberikan contoh-contoh soal yang dikerjakan oleh guru itu sendiri selanjutnya siswa diberikan tugas dalam bentuk latihan-latihan soal untuk dikerjakan, menempatkan siswa sebagai pendengar dan pencatat pemaparan materi dari guru, sehingga komunikasi yang terjadi satu arah dan kesempatan mengontrol pemahaman siswa terbatas. Guru memberi mereka tugas-tugas tanpa adanya pemeriksaan terhadap tugas tersebut. Sehingga siswa tidak serius dalam mengerjakan tugas-tugas yang diberikan guru, ada yang menyalin tugas temannya bahkan ada pula yang tidak mengerjakan tugas tersebut, padahal dengan mengerjakan tugas- tugas tersebut dapat meningkatkan kemampuan siswa untuk cepat dan tepat dalam menyelesaikan soal-soal matematika. Jadi jika mengerjakan soal ujian, siswa tidak akan mengalami kesulitan dalam hal mengingat prosedur menjawab soal. 
Beberapa siswa yang mengerti prosedur pengerjaannya tetapi karena kurang terbiasanya mengerjakan soal dengan cepat, maka siswa banyak yang tidak dapat menyelesaikan soal dengan waktu yang diberikan. Ini dapat diartikan bahwa kemampuan matematik siswa tersebut masih rendah akibatnya hasil belajar matematika siswa yang bersangkutan juga rendah. Kemampuan matematika yang dimaksud adalah kemampuan dalam operasi atau prosedur dalam mengerjakan soal matematika agar siswa dapat mencapai hasil belajar yang optimal. Walaupun kini banyak alat yang digunakan untuk menghitung cermat dan cepat. Contohnya daftar kuadrat, daftar akar dan kalkulator. Akan tetapi berhitung cermat dan cepat tanpa alat di sekolah tetap diperlukan. Karena saat ujian tentunya tidak diperkenankan menggunakan alat-alat bantu tersebut. Oleh karena itu, kemampuan matematik siswa perlu dikembangkan.

Guru bukan merupakan satu-satunya sumber belajar, melainkan guru adalah satu komponen dari sumber belajar. Selain itu, media juga berperan penting dalam membantu pembelajaran. Media adalah alat yang digunakan untuk mentransfer informasi sehingga dapat menarik perhatian, dan minat belajar siswa.

Berdasarkan latar belakang tersebut, Program Pengabdian Masyarakat (PKM) Universitas Pamulang (UNPAM) terpanggil untuk ikut serta membantu memecahkan persoalan yang dihadapi oleh peserta didik dengan judul PKM: "Memahami matematika dengan mudah dan menyenangkan di SMAN 6 Tangerang Selatan".

\subsection{Rumusan Masalah}

Berdasarkan latar belakang diatas, maka dapat dirumuskan permasalahan sebagai berikut:

1). Apakah perlu diebrikan pengenalan ke siswa/i tentang cara pembelajaran matematika yang menyenangkan?

2). Bagaimana mengenalkan proses pembelajaran ke siswa/i khususnya tentang matematika sehingga dapat menumbuhkan motivasi dalam belajar ?

\subsection{Tujuan Pengabdian Kepada Masyarakat}

Tujuan umum dari kegiatan pengabdian kepada masyarakat ini adalah membantu peserta didik dalam mengatasi persoalan-persoalan yang dihadapi dalam memahami pelajaran matematika selama proses belajar. Secara khusus tujuan kegiatan pengabdian kepada masyarakat ini adalah:

1). Membantu untuk menumbuhkan rasa percaya diri pada peserta didik dalam memahami dan belajar matematika.

2). Membantu peserta didik dalam meningkatkan pemahaman matematika.

3). Membantu peserta didik untuk meningkatkan dasar eksakta matematika sebagai prasyarat dalam mempelajari matematika.

4). Membantu peserta didik dalam meningkatkan hasil belajar matematika di sekolah. 


\subsection{Manfaat Pengabdian Kepada Masyarakat}

Universitas Pamulang (UNPAM) merupakan kampus yang berdiri di bawah naungan Yayasan Sasmita Jaya yang beralamat di Jl. Surya Kencana No. 1 Pamulang dengan mengemban visi "Bermutu dalam pengembangan pendidikan, penelitian, dan pengabdian terjangkau seluruh lapisan masyarakat, berlandaskan ridha Tuhan Yang Maha Esa". UNPAM dalam lingkup perguruan tinggi ada di dalam wilayah lingkungan Kopertis IV.

UNPAM membuka diri untuk melakukan berbagai kerjasama dengan berbagai pihak dalam rangka pengembangan ilmu, institusi, teknologi dan seni dalam rangka pelaksanaan Tri Dharma Perguruan Tinggi yakni Pendidikan, Penelitian dan Pengabdian. UNPAM sudah mempunyai jaringan dengan berbagai lembaga lain yakni pemerintah pusat, pemerintah propinsi, pemerintah kabupaten , dunia usaha, swasta maupun dengan masyarakat.

Melihat lokasi kampus yang tidak jauh dengan lokasi sekolah dan lembaga pendidikan, maka sudah menjadi kewajiban bagi perguruan tinggi untuk ikut serta membantu berbagai persoalan yang dihadapi masyarakat. Sudah selayaknya kehadiran perguruan tinggi agar dapat benar-benar dirasakan manfaatnya oleh masyarakat baik yang dekat maupun yang jauh.

\section{METODE PELAKSANAAN}

\subsection{Kerangka Pemecahan Masalah}

Persetujuan proposal pengabdian masyarakat pada kampus Universitas Pamulang di SMAN 6 Tangerang Selatan berguna untuk memberikan pengetahuan kepada siswa/i tentang bagaimana mempelajari matematika dengan cara menyenangkan.

Sasaran dari pelaksanaan program pengabdian masyarakat ini adalah mengenalkan pentingnya matematika dan bagaimana cara mempelajari matematika dengan menyenangkan. Dengan harapan siswa/i di SMAN 6 Tangerang Selatan mengetahui bagaimana cara meningkatkan motivasi belajar dan dapat memanfaatkan metode tersebut untuk meningkatkan prestasi belajar santri terhadap mata pelajaran Matematika

\subsection{Realisasi Pemecahan Masalah}

Kegiatan ini meliputi bagaimana siswa mempelajari matematika melalui beberapa cara penyelesaian yang mudah dan menyenangkan. Selanjutnya diberikan ceramah tentang matematika. Di akhir puncak acara, diadakan penyerahan plakat dari TIM PKM kepada pihak SMAN 6 Tangerang Selatan.

Persiapan dilakukan dengan mempersiapkan segala hal yang berhubungan dengan pelaksanaan acara yaitu berupa persiapan materi, bahan dan alat sesuai tema dengan cermat. Sehingga materi dapat tersampaikan dengan baik dan mudah dimengerti. 


\subsection{Khalayak Sasaran}

Sasaran program pengabdian masyarakat yang akan di tuju adalah SMAN 6 Tangerang Selatan yang beralamatkan di Pamulang Sejumlah 60 Orang. Jumlah 60 Orang itu terdiri dari:

$$
\begin{aligned}
& 30 \text { Orang }: \text { siswa/i xi ips } 1 \\
& 30 \text { Orang }: \text { siswa/I xi ips } 2
\end{aligned}
$$

\subsection{Tempat dan Waktu}
Hari/Tanggal
: Kamis - Jumat, 7 dan 8 November 2019
Waktu
: Pukul 10.30 - Selesai
Tempat
: SMAN 6 Tangerang Selatan

\subsection{Metode Kegiatan}

Metode yang akan digunakan dalam pengabdian masyarakat ini adalah melalui kegiatan:
1). Praktik
2). Ceramah

\section{HASIL DAN PEMBAHASAN}

Pelasanaan kegiatan hari pertama dilakukan setelah sholat Jum'at. Dengan rincian acara sebagai berikut:

10.30-12.00 : Pengenalan materi matematika dengan cara yang mudah.

12.00-13.00 : ishoma

13.00-14.30 : Ceramah materi Matematika barisan dan deret

Pelaksanaan kegiatan hari kedua yaitu diskusi dan penyuluhan terhadap pembina

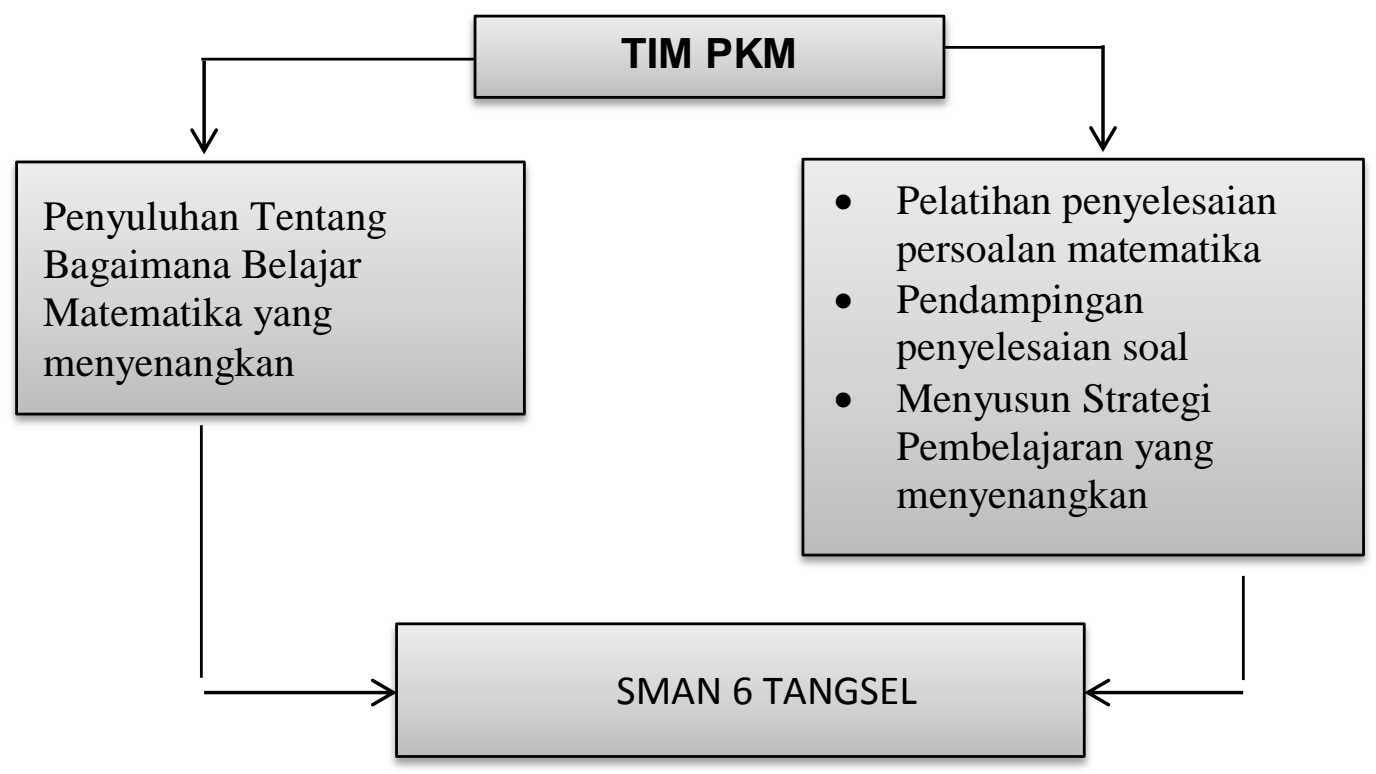




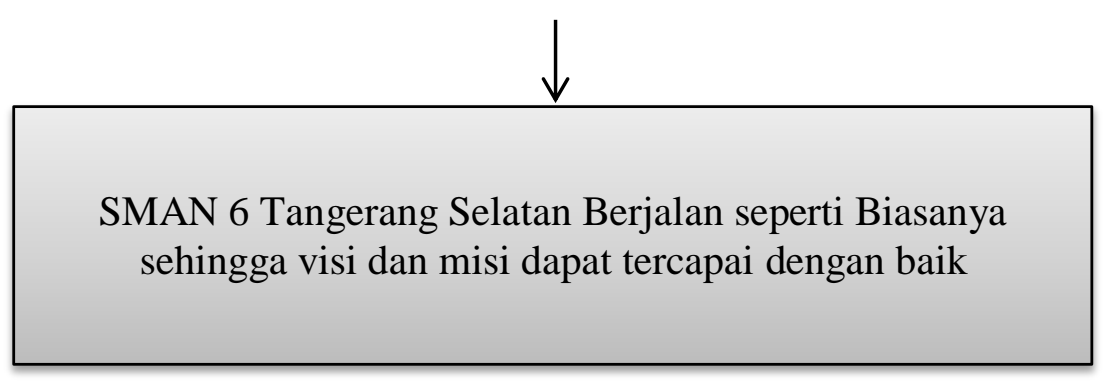

Gambar 1 Pemecahan Masalah

Perencanaan dan pelaksanaan kegiatan sering kali terjadi perbedaan berdasarkan kondisi yang dihadapi pasa saat pelaksanaan. Oleh karena itu pelaksanaan kegiatan pengabdian kepada masyarakat yang dilakukan di SMAN 6

Tangerang Selatan memerlukan evaluasi guna perbaikan pelaksanaan kegiatan mendatang

Dari hasil kegiatan yang dilakukan, berikut ini ada beberapa kondis yang perlu dicatat dan memerlukan perhatian

1). Pada pemberian materi barisan dan deret, sasaran didik siswa yang diberi penyuluhan sejumlah 30 siswa dengan satu pemateri utama. Hal tersebut mengakibatkan forum menjadi terlalu besar dan kurang efektif ditambah lagi print out materi tidak disediakan.

2). Adapun untuk lebih menarik pembelajaran, kedepannya lebih baik lagi bila dikemas dengan games yang lebih seru lagi.

\section{SIMPULAN}

Segala bentuk kegiatan yang direncanakan dan dijalankan dimaksudkan untuk mencapai tujuan, baik tujuan anggota maupun tujuan institusi. Beriringan dengan visimisi institusi yang dari sudut pandang humanis, Universitas Pamulang harus memperhatikan kondisi masyarakat di lingkungan sekitarnya

Jika perencanaan program kerja kurang maksimal akan mengakibatkan gagalnya suatu kegiatan. Oleh karena itu dalam merencanakan program harus diikuti kemampuan yang dapat diimplementasikan dalam program kerja.

Kegiatan pengabdian kepada masyarakat dalam memberikan cara untuk mudah dan menyenangkan dalam belajar matematika khusunya di SMAN 6 Tangerang Selatan dapat berjalan dengan lancar. Hampir semua peserta didik antusias dan merasakan manfaat pembelajaran. Keberhasilan ini ditunjukan antara lain oleh :

1). Adanya kesesuaian materi dengan pembelajaran yang sedang peserta didik pelajari di sekoalah.

2). Adanya respon yang positif dari peserta didik mengingat bahwa matematika saat ini dianggap sebagaia pelajaran yang cukup sulit.

3). Sebagian besar (75\%) peserta didik telah memahami konsep bagaimana cara belajar matematika agar mudah dan menyenangkan yang dapat dilihat dari hasil post test peserta didik yang cukup baik. 
Dari tanggapan dan pertanyaan peserta pengabdian, dalam hal ini peserta didik di SMAN 6 Tangerang Selatan setelah menjalani proses pembelajar merasa cukup senang, sehingga mereka lebih antusias lagi dalam belajar matematika. Demikian pula dengan pelaksanaan kegiatan pengabdian kepada masyarakat yang direncanakan dan dilaksanakan di rumah yatim dan pesantren Ruhama. Alhamdulillah dapat terlaksana dengan baik dan lancar.

\section{DAFTAR PUSTAKA}

Purcell, Edwin. (1990). Kalkulus Dan Geometri Analitik. Jakarta : Erlangga 